\title{
High COURT OF NEW ZEALAND AND TOKELAU - A RECENT CASE
}

\author{
Tony Angelo* and Ashleigh Allan ${ }^{* *}$
}

The decision of the High Court of New Zealand in the case of Pisaina Leilua-Lei Sam v The Council for the Ongoing Government of Tokelau and Faipule Foua Toloa (Sam v COG) ${ }^{1}$ provides an opportunity to consider the court system of Tokelau and to glimpse a largely unknown area of the law of New Zealand. It appears that Sam v COG is the first case $e^{2}$ to be decided by the High Court

* Professor, Faculty of Law, Victoria University of Wellington.

** BA/LLB (Hons), Law Research Officer.

1 Pisaina Leilua-Lei Sam v The Council for the Ongoing Government of Tokelau and Faipule Foua Toloa [2012] NZHC 2775, per Associate Judge Gendall.

2 Tokelau disputes have rarely been decided by courts external to Tokelau. This is probably a consequence of Tokelau's small size, lack of resources, remoteness, and a preference for alternative dispute resolution. Increased travel possibilities for the people of Tokelau and the taking of responsibility by Tokelau for its internal government have increased the possibilities for litigation involving persons outside Tokelau and consequently for the involvement of courts outside of Tokelau. Since 2000 there have been a few instances (in relation to child custody matters) where the use of the High Court of New Zealand's Tokelau jurisdiction has been contemplated. None is known to have proceeded.

Historically the High Court of Niue was thought to have some jurisdiction in respect of Tokelau matters: see for example the Tokelau Amendment Act 1970, ss 4, 7 and 8, and the Tokelau Divorce Regulations 1975, reg 2. At least two and possibly three divorces were granted by the High Court of Niue between 1975 and 1980. That jurisdiction was not available until 1 December 1975 by which time Niue had become a selfgoverning State and New Zealand legislation could no longer extend to it. In respect of the divorces granted, the matter was retrospectively corrected by s 11 of the Tokelau Amendment Act 1986. 
of New Zealand in the exercise of its jurisdiction as a separate Court of justice for Tokelau. ${ }^{3}$ This case note deals in turn with the structure of Tokelau's court system, the judgment in Sam v COG, and the future of the system.

\section{THE COURTS OF TOKELAU}

Tokelau's first constitutional engagement with a western-style court system occurred when the three New Zealand islands of Tokelau became a British protectorate in 1889. There was then, in some limited circumstances, the possibility for jurisdiction to be exercised by the High Commissioner's Court of the Western Pacific High Commission, with an ultimate right of appeal to the Judicial Committee of the Privy Council. During the British colonial period (1916-1926) the system based on the jurisdiction of the High Commissioner of the Western Pacific continued but with a wider jurisdictional base. During the period of New Zealand administration (1926-1948) the system of law was continued with the highest domestic judicial authority being exercised by the Administrator of Western Samoa, and the Governor-General of New Zealand (as Governor of Tokelau) externally fulfilling the role of the Western Pacific High Commission. ${ }^{4}$

The current structure and jurisdiction of Tokelau's judiciary is found in the Tokelau Amendment Act $1986 .^{5}$ At a village level, one Commissioner is appointed to each island of Tokelau with jurisdiction over civil claims not exceeding $\$ 1,000^{6}$ and criminal offences punishable by fine only or imprisonment for not more than one year. ${ }^{7}$ The High Court of New Zealand has jurisdiction as

3 Tokelau Amendment Act 1986, s 3:

(1) The High Court of New Zealand shall have all jurisdiction which may be necessary to administer the law of Tokelau in the same manner in all respects as if that jurisdiction had been conferred upon that Court as a separate Court of justice in and for Tokelau.

(2) The jurisdiction conferred on the High Court by subsection (1) of this section may, subject to the provisions of any regulations made under the principal Act and to the provisions of any rules made by the General Fono, be exercised in the same manner in all respects as if Tokelau was for all purposes part of New Zealand.

(3) In the exercise of the jurisdiction conferred on it by subsection (1) of this section, the High Court may sit either in Tokelau or in New Zealand, or in such other appropriate place as the Chief Justice may direct.

4 For further information on these matters see Tony Angelo and Talei Pasikale Tokelau: A History of Government (Government of Tokelau, Samoa, 2008). See especially Appendix 2 at 59-65.

5 It was introduced by the Tokelau Amendment Act 1970 which came into force on 1 December 1975 by virtue of SR 1975/261

6 Subject to an extension of the civil jurisdiction by agreement - see the Tokelau Amendment Act 1986, s 8.

7 Tokelau Amendment Act 1986, s 7. But the penalties that can be imposed by the Commissioner are limited: in the case of fines, up to $\$ 150$; and in the case of imprisonment, up to three months. There are no prisons in Tokelau; a typical punishment is the performance of community work. 
the High Court of Tokelau for claims exceeding the jurisdiction of the Commissioners and for appeals from a Commissioner's decision. ${ }^{8}$ The New Zealand Court of Appeal has jurisdiction to hear appeals from the High Court acting as a Court of justice for Tokelau. ${ }^{9}$

\section{THE CASE}

The plaintiff, Pisaina Leilua-Lei Sam, was a former Director of Finance of Tokelau based in the Tokelau Apia Liaison Office in Samoa. She claimed damages arising out of her contract of employment with the Government of Tokelau. The Government of Tokelau was represented by the Council for the Ongoing Government of Tokelau ${ }^{10}$ and Faipule Foua Toloa, the then chairperson of the Council and Minister of Finance.

The present litigation was filed in the Wellington Registry of the High Court of New Zealand, exercising jurisdiction as a superior Court of justice for Tokelau. The plaintiff sought directions on whether the appropriate rules of civil procedure applicable in the proceedings were the High Court Rules of New Zealand (High Court Rules) ${ }^{11}$ or the Tokelau Crimes, Procedure and Evidence Rules 2003 (2003 Rules). ${ }^{12}$ The plaintiff also sought directions on how service of the proceedings might be effected on the defendants.

Regarding the first issue, the Court found that the High Court as a court for Tokelau should exercise its jurisdiction and apply civil procedure rules as usual, unless they conflicted with any rules made by the General Fono. ${ }^{13}$ As a matter of interpretation, the 2003 Rules are not limited to claims under $\$ 1,000$ (which are heard in a Commissioner's Court in Tokelau) as the plaintiff argued, but also apply to the High Court of New Zealand as a Court of justice for Tokelau. The 2003 Rules

8 Tokelau Amendment Act 1986, ss 3 and 10. The High Court of New Zealand does not have jurisdiction to hear proceedings for criminal offences punishable for not more than three months imprisonment or a fine of not more than \$150: Tokelau Amendment Act 1986, s 10(3).

9 Tokelau Amendment Act 1986, s 4. Decisions of the Court of Appeal "shall be final". Quaere whether this precludes a prerogative right of appeal to the Privy Council.

10 The Council for the Ongoing Government of Tokelau (six ministers) is the successor to the Council of Faipule (three ministers) as the National Cabinet of Ministers for Tokelau. It is established by $r 6$ of the Constitution of Tokelau 2006. See also r 7 of the Administration Rules 1993.

11 High Court Rules.

12 Rule 176 provides that "[t]he rules of evidence and procedure in these rules shall have effect in place of the rules of the common law and equity relating to evidence and procedure". Rule 175 states:

Where a matter of procedure or evidence is not provided for in these rules the judge shall make such orders as the judge thinks best in the circumstances of the case to promote justice.

13 The General Fono is the Tokelau national governing body. Section 3A of the Tokelau Act 1948 provides for the General Fono to make rules. 
therefore applied to these proceedings. It is only where the 2003 Rules are silent on relevant matters which are otherwise covered by the High Court Rules, that the High Court Rules apply.

The second issue, regarding how service of documents on the defendants could be effected, was covered by r 97(1) of the 2003 Rules which provides:

(i) A court document that is to be served shall be -

(ii) served by a constable, by delivering it personally to the person to be served or, if that person cannot be conveniently found, by leaving it with some person at the last or most usual place of residence of the person to be served.

The Court found that if a defendant is in Tokelau, service in person may not be practical or convenient due to Tokelau's relative isolation and access difficulties. It was noted that suit against the Government of Tokelau was specifically dealt with by r 145 of the 2003 Rules. The first defendant, the Council for the Ongoing Government of Tokelau ${ }^{14}$ - which the Court treated as a body corporate - was directed to be served at the Tokelau Apia Liaison Office at Samoa where the principal office is. Alternatively, documents could be served on the Administrator of Tokelau at the Special Relations Unit of the Ministry of Foreign Affairs and Trade Office in Wellington. In respect of the second defendant, the Court directed that endeavours should be made to effect service in accordance with $\mathrm{r}$ 97(1), and if service were not effected within a reasonable period by that method, the documents could be served by mailing them to the defendant at the Tokelau Apia Liaison Office in Samoa, or personally, on a "responsible occupant" at the Tokelau Apia Liaison Office.

In the exercise of its jurisdiction in respect of Tokelau "the High Court may sit either in Tokelau or in New Zealand, or in such other appropriate place as the Chief Justice may direct". ${ }^{15}$ Rule 87 of the 2003 Rules further states that "[e]very civil case and every criminal appeal in the High Court or in the Court of Appeal shall, unless the court otherwise directs, be decided on the papers". ${ }^{16}$ Where proceedings raise a matter of Tokelau custom, the Custom as a Source of Law Rules 2004 provide that the High Court will seek the advice of the General Fono on that matter of custom.

\section{THE FUTURE}

The future of Tokelau's court system is likely to be a continuation of the present pattern. The population of approximately 1,400 people dispersed over three remote atolls near the equator formally requires a court system, but there is little call for an elaborate system on a day-to-day basis.

14 Established by $\mathrm{r} 6$ of the Constitution of Tokelau 2006.

15 Tokelau Amendment Act 1986, s 3(3).

16 Right of audience in a court of Tokelau is governed by $\mathrm{r} 95$ of the Tokelau Crimes, Procedure and Evidence Rules 2003. 
The present structure can provide the necessary support for the foreseeable future. The draft Constitution for a Tokelau in Free Association with the State of New Zealand 2005 envisaged the continuation of the current system after the (anticipated) self-determination by Tokelau.

On a day-to-day basis the judicial work, mainly of a criminal law nature, is performed by local lay judges. The present focus and that for the immediate future is on strengthening the operation of the Commissioner's Courts and on providing improved police and other support facilities within the community. The Tokelau Judicial Annual Report July 2011-June $2012{ }^{17}$ provides evidence of the operation of the Commissioner's Courts and information on current development strategies.

17 Government of Tokelau Tokelau Judicial Annual Report July 2011-June 2012 (Apia, 2012). This is the first formal report on the judiciary of Tokelau and the delivery of judicial services in the three villages. The report was produced with assistance from the Pacific Judicial Development Programme. 
